\title{
PENGARUH BUDAYA ORGANISASI, STRES KERJA DAN KOMITMEN TERHADAP KINERJA KARYAWAN CV. BINTANG KARYA PUTRA DI SURABAYA
}

\author{
H. Edy Sutrisno \\ binkop_bkp@ymail.com \\ Pascasarjana Universitas 17 Agustus 1945 (UNTAG) Surabaya
}

\begin{abstract}
$C V$. Bintang Karya Putra in Surabaya is one of a private company in construction area and cleaning service. In facing emulation is required by pre-eminent human resource and professional, therefore hardly is required quality of human resource, causing can reach optimal performance executed by all company employee. Employee performance hardly influenced by organization culture, stress job and commitment of employee. This research aim to know are there influence between organization cultures, stres job and commitment to employee performance. Sample taken is 75 employees of $C V$. Bintang Karya Putra in Surabaya. Based on result of knowable finding:

1. Based on result of the research earns to know that there are significant influence between organization culture to employee performance of $C V$. Bintang Karya Putra.

2. Based on result of research earns to know that there are significant influence between job stres to employee performance of $C V$. Bintang Karya Putra.

3. Based on result of the research earns to know that there are significant influence between commitment to employee performance of CV. Bintang Karya Putra.

4. Variable that is very dominant influential to employee performance of $C V$. Bintang Karya Putra is variable organization culture.

5. Contribution given by organization culture, stress job and commitment to employee performance of $C V$. Bintang Karya Putra is $83,50 \%$. While the rest $16,50 \%$ is variables that is not predicted in this research.
\end{abstract}

Key word: Organization Culture, Job Stres, Commitment and Employee performance.

\section{PENDAHULUAN}

Di era globalisasi saat ini organisasi dituntut untuk terus menerus mempersiapkan dirinya mengantisipasi dan menyesuaikan diri dengan perubahan. Pengalaman yang dialami berbagai organisasi di negara maju menunjukkan bahwa hanya organisasi yang secara konsisten terus meningkatkan dirinya melalui pengembangan organisasi yang dapat bertahan. Oleh karena itu dibutuhkan sumber daya yang unggul. 
Persoalan kebutuhan memperoleh sumber daya manusia yang unggul dan profesional yang diharapkan banyak badan usaha dan perusahaan di Indonesia untuk bisa bersaing pada era keterbukaan, membuat dunia industri menghadapi tantangan yang berat untuk dapat bersaing baik secara regional, nasional maupun internasional. Maraknya persaingan dan tuntutan profesionalitas karyawan yang semakin tinggi menimbulkan banyaknya tekanan-tekanan yang harus dihadapi individu dalam lingkungan kerja.

Dalam kondisi lingkungan kerja yang penuh dengan tekanan tersebut, karyawan diharapkan juga untuk memiliki komitmen yang besar terhadap perusahaan dimana karyawan tersebut bekerja. Sebab dengan memiliki komitmen yang tinggi berarti karyawan tersebut secara konsisten akan mencapai kinerja yang optimal untuk memajukan perusahaan. Sehingga kinerja karyawan dipengaruhi oleh budaya organisasi, stress kerja dan komitmen.

Budaya organisasi sering diartikan sebagai seperangkat nilai-nilai, keyakinan-keyakinan, atau norma-norma yang telah lama dianut bersama oleh para anggota organisasi (karyawan), sebagai pedoman perilaku dan memecahkan masalah-masalah organisasinya. Nilai ialah sesuatu yang dipandang penting, berharga, diprioritaskan, dan diperjuangkan untuk dilaksanakan. Keyakinan ialah sesuatu yang diterima sebagai kebenaran dan tidak diperdebatkan dan norma ialah pedoman atau aturan yang harus ditaati oleh para anggota organisasi. Misalnya karyawan baru yang ada di perusahaan diperlukan penyesuian terlebih dahulu dengan lingkungan yang baru. Ada delapan butir nilai-nilai primer yang seharusnya ada pada tiap-tiap perusahaan atau organisasi yang jika dikelola dengan baik dapat menjadi budaya organisasi yang positif, dan akan mengakibatkan loyalitas dan produktivitas. Delapan butir nilai-nilai budaya itu disebut sebagai asas-asas, yaitu: asas tujuan, asas konsensus, asas keunggulan, asas prestasi, asas kesatuan, asas empiris, asas keakrapan, dan asas integritas.

Berbicara tentang budaya organisasi, biasanya yang dimaksud ialah adanya persepsi yang sama di kalangan seluruh anggota organisasi tentang makna hakiki kehidupan bersama. Pengertian sederhana tersebut sesungguhnya berarti, bahwa dalam lingkungan suatu organisasi mutlak diperlukan pemahaman yang tepat tentang cara-cara bertindak dan berperilaku yang baik bagi organisasi. Implikasinya yang sangat mendasar ialah, bahwa kehadiran dan keberadaan seseorang sebagai anggota organisasi hanya akan diterima oleh berbagai pihak lain, seperti atasan langsung, manajemen, dan rekan-rekan setingkat apabila yang bersangkutan mau, mampu, dan bersedia melakukan berbagai jenis penyesuaian dalam tindakan dan perilakunya sehingga mencerminkan penerimaannya tentang budaya organisasi

Berikutnya stress kerja juga berpengaruh terhadap kinerja karyawan jika dikaitkan dengan pekerjaan. Stress kerja yang terlalu ringan biasanya akan menimbulkan akibat yang kurang baik bagi karyawan, misalnya karyawan merasa bosan dengan pekerjaan 
sehingga kinerja menurun. Sedangkan stress kerja dalam keadaan optimal biasanya menghasilkan kinerja yang tinggi, kondisi stress kerja seperti inilah yang diharapkan dapat muncul dalam situasi kerja sehingga mampu memotivasi karyawan untuk dapat bekerja lebih produktif.

Selain budaya organisasi dan stress kerja, komitmen juga dapat mempengaruhi kinerja seorang karyawan, yaitu komitmen dari semua elemen-elemen yang ada dalam organisasi dari para pelaksana sampai pimpinan organisasi. Komitmen karyawan merupakan hal yang penting bagi organisasi, terutama untuk menjaga kelangsungan dan pencapaian tujuan. Namun untuk memperoleh komitmen yang tinggi, diperlukan kondisi-kondisi yang memadai untuk mencapainya. Namun untuk melakukan hal tersebut tidak mudah. Komitmen SDM diperlukan sebagai salah satu untuk meningkatkan kinerja karyawan. Komitmen yang tinggi dapat diharapkan akan memperlihatkan kinerja yang optimal. Komitmen karyawan merupakan hal yang penting bagi organisasi, terutama untuk menjaga kelangsungan dan pencapaian tujuan. Namun untuk memperoleh komitmen yang tinggi, diperlukan kondisi-kondisi yang memadai untuk mencapainya.

Sedangkan kinerja merupakan bagaimana seseorang diharapkan dapat berfungsi dan berperilaku sesuai dengan tugas yang telah dibebankan kepadanya. Setiap harapan mengenai bagaimana seseorang harus berperilaku dalam melaksanakan tugas, berarti menunjukkan suatu peran seorang karyawan yang diharapkan dalam budaya organisai yang ada dalam perusahaan.

Seperti halnya CV. Bintang Karya Putra di Surabaya merupakan salah satu perusahaan swasta di bidang jasa kontruksi dan cleaning service, dimana dalam mempertahankan perusahaannya agar tetap survival, harus memberikan pelayan sebaik mungkin kepada para konsumen, dengan jalan meningkatkan pelayanan kepada konsumen yaitu dengan cara meningkatkan kinerja karyawannya.

Berdasarkan uraian pada pendahuluan diatas maka rumusan masalah yang dikemukakan dalan penelitian ini adalah sebagai berikut:

1. Apakah budaya organisasi mempunyai pengaruh yang signifikan terhadap kinerja karyawan CV. Bintang Karya Putra di Surabaya?

2. Apakah stress kerja mempunyai pengaruh yang signifikan terhadap kinerja karyawan CV. Bintang Karya Putra di Surabaya ?

3. Apakah komitmen mempunyai pengaruh yang signifikan terhadap kinerja karyawan CV. Bintang Karya Putra di Surabaya ?

4. Diantara ketiga variabel bebas diatas manakah yang mempunyai pengaruh dominan terhadap kinerja karyawan CV. Bintang Karya Putra di Surabaya ?

5. Besarnya kontribusi masing-masing variabel bebas terhadap kinerja karyawan CV. Bintang Karya Putra di Surabaya? 


\section{RERANGKA TEORETIS}

\section{Budaya Organisasi}

Budaya organisasi adalah suatu konsep yang sangat bervariasi, terbukti dari adanya sekian banyak pendapat yang berbeda-beda yang dapat ditemukan dalam kepustakaan. Hal ini disebabkan oleh berbagai pandangan, pendekatan, minat masing-masing yang berkepentingan dari berbagai kalangan, baik dari kalangan akademisi maupun praktisi.

Setiap organisasi memiliki definisi yang berbeda-beda mengenai budaya organisasi. Menurut Robins (2006) Budaya organisasi merupakan sistem nilai bersama dalam suatu organisasi yang menentukan tingkatan bagaimana para karyawan melakukan kegiatan untuk mencapai tujuan organisasi. Moeljono (2005), budaya organisasi adalah keyakinan bersama dan nilai bersama yang memberikan makna bagi anggota sebuah institusi dan menjadikan keyakinan dan nilai tersebut sebagai aturan atau pedoman berperilaku di dalam organisasi.

Budaya organisasi juga disebut budaya perusahaan, yaitu seperangkat nilai-nilai atau norma-norma yang telah relatif lama berlakunya, dianut bersama oleh para anggota organisasi (karyawan) sebagai norma perilaku dalam menyelesaikan masalah-masalah organisasi (perusahaan). Dalam budaya organisasi terjadi sosialisasi nilai-nilai dan menginternalisasi dalam diri para anggota, menjiwai orang per orang di dalam organisasi.

Budaya organisasi merupakan faktor yang paling kritis dalam organisasi. Efektivitas organisasi dapat ditingkatkan dengan menciptakan budaya yang kuat, yang dapat digunakan untuk mencapai tujuan organisasi. Organisasi yang berbudaya kuat akan memiliki ciri khas tertentu sehingga dapat memberikan daya tarik bagi individu untuk bergabung. Suatu budaya yang kuat merupakan perangkat yang sangat bermanfaat untuk mengarahkan perilaku, karena membantu karyawan untuk melakukan pekerjaan dengan lebih baik, sehingga setiap karyawan perlu memahami budaya dan bagaimana budaya tersebut terimplementasikan (Moeljono, 2003).

Robbins (2006), karena menimbulkan antara lain sebagai berikut: (a) Nilai-nilai kunci yang saling jalin menjalin, tersosialisasikan, menginternalisasi, menjiwai pada para anggota, dan merupakan kekuatan yang tidak nampak; (b) Perilaku-perilaku karyawan secara tak disadari terkendali dan terkoordinasi oleh kekuatan yang informal atau tidak tampak; dan (c) Para anggota merasa komit dan loyal pada organisasi.

Definisi-definisi yang dijelaskan tersebut diatas satu sama lain berbeda-beda, tetapi terdapat satu kesamaan benang merahnya, yaitu kebersamaan arti para karyawan di dalam organisasi, apakah mengenai pikiran, perilaku, nilai-nilai, norma-norma, dan lain sebagainya. 
Jadi budaya organisasi yang benar-benar dikelola sebagai alat manajemen akan berpengaruh dan menjadi pendorong bagi karyawan untuk berperilaku positif, dedikatif, dan produktif. Nilai-nilai budaya itu tidak tampak, tetapi merupakan kekuatan yang mendorong perilaku untuk menghasilkan efektivitas kinerja.

\section{Stress Kerja}

Stres akan menyebabkan terganggunya fungsi emosi, kognitif maupun fisiologik individu yang mengalaminya. Bagi individu yang mempunyai penyesuaian diri baik, stress akan dengan mudah dan cepat ditanggulangi, tapi bagi yang penyesuaian dirinya jelek, stress akan menimbulkan masalah dalam setiap langkah kehidupan individu.

Stres sebagai suatu istilah payung yang merangkumi tekanan, beban, konflik, keletihan, ketegangan, panik, perasaan gemuruh, anxieti, kemurungan dan hilang daya. Stres kerja adalah suatu kondisi ketegangan yang menciptakan adanya ketidakseimbangan fisik dan psikis, yang mempengaruhi emosi, proses berpikir, dan kondisi seorang karyawan. Stres yang terlalu besar dapat mengancam kemampuan seseorang untuk menghadapi lingkungan. Sebagai hasilnya, pada diri para karyawan berkembang berbagai macam gejala stress yang dapat mengganggu pelaksanaan kerja mereka. Orang-orang yang mengalami stress bisa menjadi nervous dan merasakan kekuatiran kronis. Mereka sering menjadi mudah marah dan agresi, tidak dapat relaks, atau menunjukkan sikap yang tidak kooperatif (Rivai, 2005).

Stres sebagai suatu tanggapan dalam menyesuaikan diri yang dipengaruhi oleh perbedaan individu dan proses psikologis, sebagai konsekuensi dari tindakan. Lingkungan, situasi atau peristiwa yang terlalu banyak mengadakan tuntutan psikologis dan fisik seseorang. Robbins memberikan definisi stres sebagai suatu kondisi dinamis di mana individu dihadapkan pada kesempatan, hambatan dan keinginan dan hasil yang diperoleh sangatlah penting tetapi tidak dapat dipastikan (Robbins, 2006). Stres sebagai suatu kekuatan yang menekan individu untuk memberikan tanggapan terhadap stresor. Pendekatan stimulus-respon mendefinisikan stres sebagai konsekuensi dari interaksi antara stimulus lingkungan dengan respon individu (Robbins, 2006).

Dengan demikian dapat disimpulkan bahwa stres kerja timbul karena tuntutan lingkungan dan tanggapan setiap individu dalam menghadapinya dapat berbeda. Masalah Stres kerja di dalam organisasi atau unit kerja menjadi gejala yang penting diamati sejak mulai timbulnya tuntutan untuk efisien di dalam pekerjaan.

\section{Komitmen}

Robbins dan Judge (2007) mendefinisikan komitmen sebagai suatu keadaan dimana seorang individu memihak organisasi serta tujuan-tujuan dan keinginannya untuk mempertahankan keanggotaannya dalam organisasi. Sedangkan Mathias dan Jackson (dalam Sasono, 2004) mendefinisikan komitmen organisasional sebagai derajad dimana 
karyawan percaya dan mau menerima tujuan-tujuan organisasi dan akan tetap tinggal atau tidak akan meninggalkan organisasinya.

Komitmen terhadap organisasi artinya lebih dari sekedar keanggotaan formal, karena meliputi sikap menyukai organisasi dan kesediaan untuk mengusahakan tingkat upaya yang tinggi bagi kepentingan organisasi demi pencapaian tujuan. Berdasarkan definisi ini, dalam komitmen organisasi tercakup unsur loyalitas terhadap organisasi, keterlibatan dalam pekerjaan, dan identifikasi terhadap nilai-nilai dan tujuan organisasi.

Komitmen pegawai pada organisasi tidak terjadi begitu saja, tetapi melalui proses yang cukup panjang dan bertahap. Steers (dalam Sopiah, 2008) menyatakan tiga faktor yang mempengaruhi komitmen seorang karyawan antara lain: (1) Ciri pribadi pekerja termasuk masa jabatannya dalam organisasi, dan variasi kebutuhan dan keinginan yang berbeda dari tiap karyawan, (2) Ciri pekerjaan, seperti identitas tugas dan kesempatan berinteraksi dengan rekan sekerja; dan (3) Pengalaman kerja, seperti keterandalan organisasi di masa lampau dan cara pekerja-pekerja lain mengutarakan dan membicarakan perasaannya tentang organisasi.

Rendahnya komitmen mencerminkan kurangnya tanggung jawab seseorang dalam menjalankan tugasnya. Mempersoalkan komitmen sama dengan mempersoalkan tanggung jawab, dengan demikian ukuran komitmen seorang pimpinan yang dalam hal ini adalah supervisor terkait dengan pendelegasian wewenang (empowerment). Dalam konsep ini pimpinan dihadapkan pada komitmen untuk mempercayakan tugas dan tanggung jawab ke bawahan. Sebaliknya, bawahan perlu memiliki komitmen untuk meningkatkan kompetensi diri

\section{Kinerja}

Kegiatan yang paling lazim dinilai suatu organisasi adalah kinerja karyawan, yakni bagaimana karyawan melakukan segala sesuatu yang berhubungan dengan suatu pekerjaan, jabatan, atau peranan dalam organisasi. Kinerja karyawan adalah yang mempengaruhi seberapa banyak mereka memberi kontribusi kepada organisasi.

Perbaikan kinerja baik untuk individu maupun kelompok menjadi pusat perhatian dalam upaya meningkatkan kinerja organisasi. Istilah kinerja berasal dari kata Job Performance atau Actual Performance (prestasi kerja atau prestasi sesungguhnya yang dicapai oleh seseorang). Pengertian kinerja merupakan hasil kerja secara kualitas dan kuantitas yang dicapai oleh seorang karyawan dalam melaksanakan tugasnya sesuai dengan tanggung jawab yang diberikan kepadanya (Mangkunegara, 2005).

Kinerja pada dasarnya adalah apa yang dilakukan atau tidak dilakukan karyawan sehingga mereka mempengaruhi seberapa banyak mereka memberi kontribusi kepada instansi atau organisasi termasuk kualitas pelayanan yang disajikan. Pada umumnya 
kinerja diberi batasan sebagai kesuksesan seseorang di dalam melaksanakan suatu pekerjaan. Secara definitif Bernardin dan Russel (dalam Sulistiyani dan Rosidah, 2003), menjelaskan kinerja merupakan catatan out come yang dihasilkan dari fungsi karyawan tertentu atau kegiatan yang dilakukan selama periode waktu tertentu.

Faustino Cardosa Gomes (dalam Mangkunegara, 2005) mengemukakan definisi kinerja sebagai ungkapan seperti output, efisiensi serta efektivitas sering dihubungkan dengan produktivitas. Jadi dapat disimpulkan kinerja karyawan adalah prestasi yang diperoleh seseorang dalam melakukan tugas.

\section{METODE PENELITIAN}

\section{Obyek, Populasi dan Sampel Penelitian}

Obyek yang digunakan dalam penelitian ini adalah CV. Bintang Karya Putra di Surabaya. Sedangkan populasi yang digunakan adalah karyawan pada CV. Bintang Karya Putra di Surabaya yang berjumlah 75 orang.

Sampel adalah sebagian dari jumlah dan karakteristik yang dimiliki oleh populasi tersebut (Sugiyono, 2003). Sedangkan teknik yang digunakan untuk menentukan sampel penelitian ini adalah dengan metode sensus yaitu sampel yang menggunakan atau mengumpulkan informasi dari seluruh responden yang ada dalam perusahaan. Sampel yang diambil dalam penelitian ini adalah dari 75 karyawan, yaitu keseluruhan dari populasi yang ada.

\section{Teknik Analisis data}

Analisa yang di gunakan dalam penelitian ini adalah dengan metode statistik. Dengan bantuan Statistical Program for Social Science (SPSS). Tujuannya untuk mengetahui pengaruh variabel bebas terhadap variabel tergantung. Persamaan variabel yang diperoleh dari proses perhitungan regresi, harus di uji secara statistik nilai regresinya. Hasil regresi yang di peroleh dapat dipergunakan untuk memprediksi nilai variabel tergantung, jika nilai-nilai variabel bebas ditentukan. Analisa regresi yang akan digunakan dalam penelitian ini adalah, uji korelasi, persamaan regresi berganda, uji F (uji secara simultan), dan uji t (uji secara parsial).

\section{Uji Asumsi Klasik}

\section{Uji Autokorelasi}

Untuk mengetahui apakah model persamaan regresi linier berganda yang tidak memiliki autokorelasi maka dapat dilakukan uji Durbin Watson dengan ketentuan sebagai berikut: Dari hasil perhitungan nilai Durbin Watson sebesar 1,911 yang terletak di daerah tidak ada autokorelasi $(1,55<\mathrm{Dw}<2,46)$, sehingga dapat 
disimpulkan bahwa pada model regresi linier berganda yang telah didapat tidak terdapat autokorelasi.

Hal ini berarti bahwa model regresi linier berganda yang dihasilkan pada perhitungan di atas dapat digunakan untuk memprediksi nilai variabel tergantung kinerja karyawan CV. Bintang Karya Putra di Surabaya pada nilai variabel bebas yang meliputi budaya organisasi, stres kerja dan komitmen, sehingga menghasilkan tes signifikansi yang akurat.

\section{Uji Heteroskedastisitas}

Deteksi untuk mengetahui adanya heteroskedastisitas adalah dengan melihat ada tidaknya pola tertentu pada grafik di bawah, di mana sumbu $\mathrm{X}$ adalah $\mathrm{Y}$ yang telah diprediksi, dan sumbu y adalah residu (Y prediksi - Y sesungguhnya) yang telah di studentised.

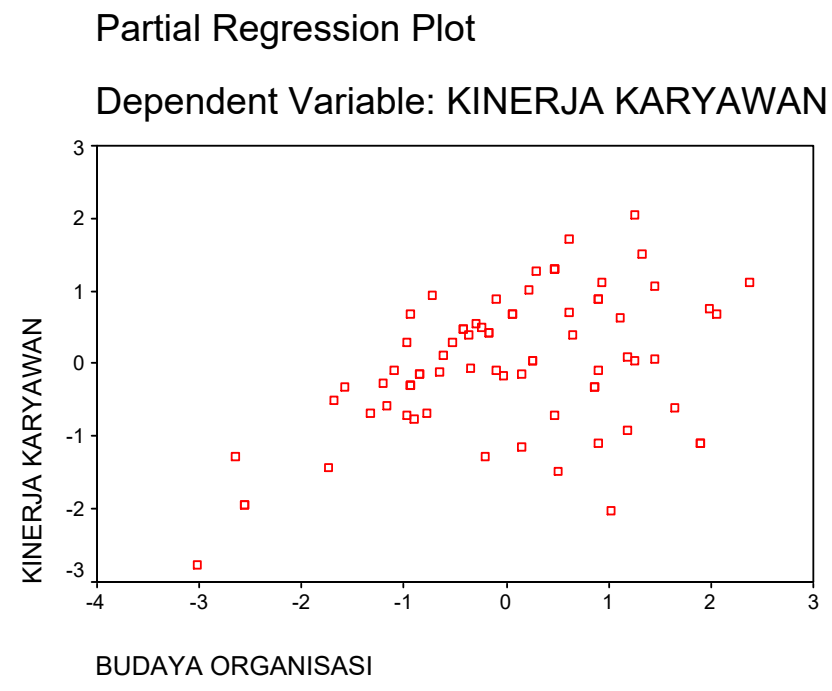

Gambar 1

Partial Regression Plot

Dari gambar 1, dapat diketahui bahwa terdapat pola yang menyebar baik di atas maupun di bawah angka 0 di sumbu Y. Hal ini berarti tidak terjadi masalah heteroskedastisitas pada model regresi yang digunakan dalam penelitian ini, sehingga model regresi layak dipakai untuk mengetahui pengaruh faktor budaya organisasi terhadap kinerja karyawan CV. Bintang Karya Putra di Surabaya. 
Partial Regression Plot

Dependent Variable: KINERJA KARYAWAN

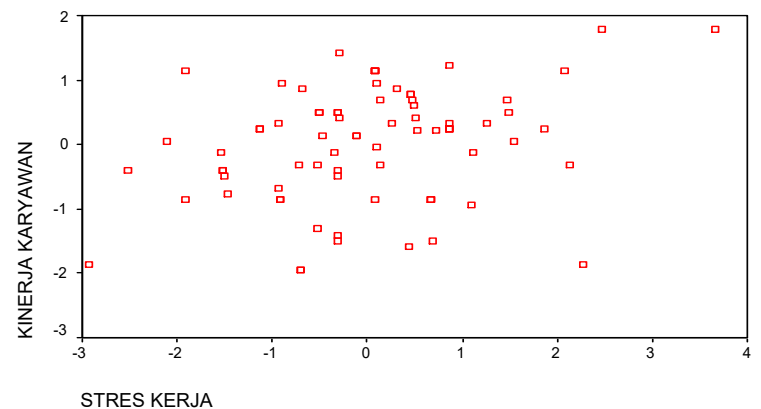

Gambar 2

Partial Regression Plot

Dari gambar 2, dapat diketahui bahwa terdapat pola yang menyebar baik di atas maupun di bawah angka 0 di sumbu $\mathrm{Y}$. Hal ini berarti tidak terjadi masalah heteroskedastisitas pada model regresi yang digunakan dalam penelitian ini, sehingga model regresi layak dipakai untuk mengetahui pengaruh faktor stres kerja terhadap kinerja karyawan CV. Bintang Karya Putra di Surabaya.

Partial Regression Plot

Dependent Variable: KINERJA KARYAWAN

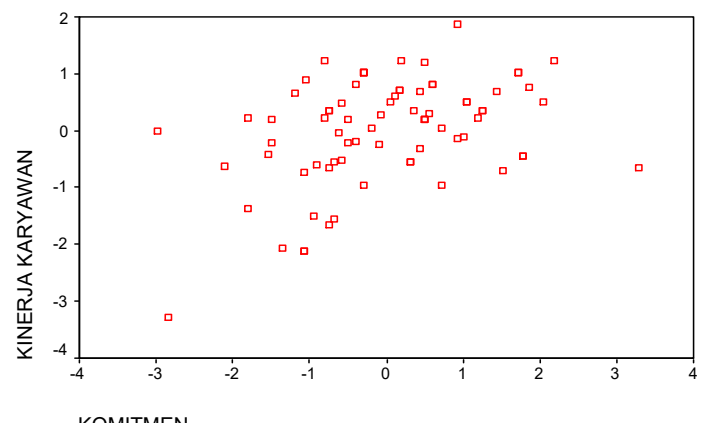

Gambar 3

Partial Regression Plot

Dari gambar 3, dapat diketahui bahwa terdapat pola yang menyebar baik di atas maupun di bawah angka 0 di sumbu Y. Hal ini berarti tidak terjadi masalah heteroskedastisitas pada model regresi yang digunakan dalam penelitian ini, sehingga model regresi layak dipakai untuk mengetahui pengaruh faktor Komitmen terhadap Kinerja Karyawan CV. Bintang Karya Putra di Surabaya. 


\section{Uji Multikolineritas}

Dari hasil penelitian dapat diketahui VIF (Variance Inflation Factor) untuk Budaya Organisasi sebesar 3,004, untuk Stres Kerja sebesar 4,224 dan untuk Komitmen sebesar 3,995 atau < dari 10. Sedangkan nilai Tolerance semua variabel mendekati 1 , maka dapat disimpulkan model regresi yang digunakan dalam penelitian ini bebas dari masalah multikolineritas.

Setelah semua uji asumsi yang ditetapkan dilakukan, maka analisa data dilanjutkan dengan menggunakan analisa regresi dengan menggunakan program SPSS (Statistical Program for Sosial Science) dengan hasil :

\section{Uji Korelasi}

Tabel 1

Uji Korelasi dan determinan

\begin{tabular}{lccccc}
\multicolumn{5}{c}{ Model Summary $^{\mathbf{b}}$} \\
\hline \hline Model & $\mathbf{R}$ & R Square & Adjusted R Square & $\begin{array}{l}\text { Std. Error of } \\
\text { the Etimate }\end{array}$ & Durbin-W atson \\
\hline 1 & $.914^{\mathrm{a}}$ & .835 & .828 & .86252 & 1.911 \\
\hline $\begin{array}{l}\text { a.Predictors: (Constant), Komitmen, Budaya Organisasi, Stres } \\
\text { b.Dependent Variable: Kinerja Karyawan }\end{array}$ &
\end{tabular}

Berdasarkan perhitungan dengan menggunakan produk momen dapat diketahui $\mathrm{R}=0,914$, ini menujukkan bahwa budaya organisasi, stres kerja, dan komitmen mempunyai korelasi yang positif terhadap kinerja karyawan CV. Bintang Karya Putra di Surabaya. Selanjutnya untuk mengetahui kontribusi yang diberikan oleh variabel bahwa budaya organisasi, stres kerja, dan komitmen mempunyai korelasi yang positif terhadap kinerja karyawan CV. Bintang Karya Putra di Surabaya, dapat diketahui bahwa $\mathrm{R}^{2}$ (koefisien determinan $)=83,50 \%$. Artinya bahwa variabel-variabel budaya organisasi, stres kerja, dan komitmen memberikan kontribusi terhadap kinerja karyawan CV. Bintang Karya Putra di Surabaya sebesar 83,50\%. Sedangkan sisanya 16,50\% adalah merupakan variabel-variabel yang tidak terprediksi dalam penelitian ini.

\section{Uji Persamaan Regresi Linier Berganda}

Dari hasil perhitungan analisis regresi berganda yang menggunakan bantuan komputer dengan memakai program SPSS didapat hasil sebagai berikut:

$$
\mathrm{Y}=5,877+0,361 \mathrm{X}_{1}+0,230 \mathrm{X}_{2}+0,315 \mathrm{X}_{3}
$$

Dari persamaan di atas, dapat diinterprestasikan sebagai berikut: 
- $\mathrm{a}=5,877$, nilai ini mengandung pengertian bahwa tanpa adanya pengaruh budaya organisasi, stres kerja dan komitmen atau $\mathrm{X}_{1}, \mathrm{X}_{2}, \mathrm{X}_{3}$, $=0$, maka kinerja karyawan $\mathrm{CV}$. Bintang Karya Putra di Surabaya akan sebesar 5,877.

- $\mathrm{b}_{1}=0,361$, nilai ini mengandung pengertian bahwa apabila Budaya Organisasi $\left(\mathrm{X}_{1}\right)$ naik sebesar satu satuan, maka akan diikuti kenaikan Kinerja Karyawan CV. Bintang Karya Putra di Surabaya (Y) sebesar 0,361.

- $\mathrm{b}_{2}=0,230$, nilai ini mengandung pengertian bahwa apabila Stres Kerja $\left(\mathrm{X}_{2}\right)$ naik sebesar satu satuan, maka akan diikuti kenaikan Kinerja Karyawan CV. Bintang Karya Putra di Surabaya (Y) sebesar 0,230.

- $\mathrm{b}_{3}=0,315$, nilai ini mengandung pengertian bahwa apabila komitmen $\left(\mathrm{X}_{3}\right)$ naik sebesar satu satuan, maka akan diikuti kenaikan Kinerja Karyawan CV. Bintang Karya Putra di Surabaya (Y) sebesar 0,315.

Hasil pengujian persamaan regresi linier berganda tersebut di atas, dapat ditarik kesimpulan bahwa variabel yang dominan terhadap Kinerja Karyawan yang paling besar adalah Budaya Organisasi yaitu beta sebesar 0,326. Dengan adanya kenyataan tersebut di atas, maka variabel yang paling dominan menurut analisis tersebut adalah variabel Budaya Organisasi.

\section{Uji F (Uji secara simultan)}

Dalam uji $\mathrm{F}$ biasanya disebut uji hipotesis simultan ini, yang mana hasilnya pengolahan tersebut dapat dilihat pada tabel berikut ini:

Tabel 2

Pengaruh Variabel Bebas Secara simultan Terhadap Variabel Tergantung

ANOVA

\begin{tabular}{lccccc}
\hline \hline Model & $\begin{array}{c}\text { Sum of } \\
\text { Squares }\end{array}$ & Df & Mean Square & F & Sig. \\
\hline 1 Regression & 267.367 & 3 & 89.122 & 119.797 & $.000^{\text {a }}$ \\
Residual & 52.820 & 71 & .744 & & \\
$\quad$ Total & 320.187 & 74 & & & \\
\hline
\end{tabular}

a. Predictors: (Constant). Komitmen, Budaya Organisasi, Stres Kerja

b.Dependent Variable: Kinerja Karyawan

Dari tabel 2 di atas, dapat diketahui bahwa F hitung sebesar 119,797, pada Sig. =0,000, ini menunjukkan bahwa secara simultan Budaya Organisasi, Stres Kerja dan Komitmen mempunyai pengaruh yang signifikan terhadap Kinerja Karyawan CV. Bintang Karya Putra di Surabaya. Artinya bahwa budaya organisasi, stres kerja dan komitmen dapat dijadikan sebagai dasar untuk memprediksi terhadap kinerja karyawan CV. Bintang 
Karya Putra di Surabaya. Ini menunjukkan bahwa hipotesis yang diajukan didukung oleh data.

\section{Uji t (Uji secara parsial)}

Tabel 3

Pengaruh Variabel bebas Secara Parsial Terhadap Variabel Tergantung

\section{Coefficients}

\begin{tabular}{lccccccc}
\hline \hline \multicolumn{1}{c}{ Model } & \multicolumn{2}{c}{$\begin{array}{c}\text { Unstandardized } \\
\text { Coefficients }\end{array}$} & $\begin{array}{c}\text { Standardized } \\
\text { Coefficients }\end{array}$ & $\mathbf{t}$ & Sig. & \multicolumn{2}{c}{$\begin{array}{c}\text { Collinearity } \\
\text { Statistics }\end{array}$} \\
\hline & $\mathrm{B}$ & Std.Error & Beta & & & Tolerance & VIF \\
\hline 1 (Constant) & 5.877 & 1.564 & & 3.759 & .000 & & \\
Budaya Organisasi & .361 & .086 & .350 & 4.196 & .000 & .333 & 3.004 \\
Stres Kerja & .230 & .084 & .271 & 2.731 & .008 & .237 & 4.224 \\
Komitmen & .315 & .084 & .359 & 3.725 & .250 & .250 & 3.959 \\
& & & & & & &
\end{tabular}

a. Dependent Variable: Kinrja Karyawan

1. Diperoleh hasil analisis yang menunjukkan bahwa ada pengaruh yang signifikan antara budaya organisasi $\left(\mathrm{X}_{1}\right)$ terhadap kinerja karyawan CV. Bintang Karya Putra di Surabaya (Y). Ini terbukti dari nilai $t=4,193$ pada Sig. $=0,000$. Artinya bahwa budaya organisasi dapat dijadikan sebagai dasar untuk memprediksi kinerja karyawan CV. Bintang Karya Putra di Surabaya.

2. Diperoleh hasil analisis yang menunjukkan bahwa ada pengaruh yang signifikan antara stres kerja $\left(\mathrm{X}_{2}\right)$ terhadap kinerja karyawan CV. Bintang Karya Putra di Surabaya (Y). Ini terbukti dari nilai $\mathrm{t}=2,731$, pada Sig. $=0,008$. Artinya bahwa stres kerja dapat dijadikan sebagai dasar untuk memprediksi kinerja karyawan CV. Bintang Karya Putra di Surabaya.

3. Diperoleh hasil analisis yang menunjukkan bahwa ada pengaruh yang signifikan antara komitmen $\left(\mathrm{X}_{3}\right)$ terhadap kinerja karyawan CV. Bintang Karya Putra di Surabaya (Y). Ini terbukti dari nilai $t=3,725$, pada Sig. $=0,000$. Artinya bahwa komitmen dapat dijadikan sebagai dasar untuk memprediksi terhadap kinerja karyawan CV. Bintang Karya Putra di Surabaya.

\section{ANALISIS DAN PEMBAHASAN}

\section{Pengaruh Budaya Organisasi terhadap Kinerja Karyawan}

Berdasarkan hasil penelitian, dapat diketahui bahwa ada pengaruh yang signifkan antara budaya organisasi terhadap kinerja karyawan CV. Bintang Karya Putra di Surabaya, 
artinya bahwa budaya organisasi dapat dijadikan sebagai dasar untuk memprediksi kinerja karyawan CV. Bintang Karya Putra di Surabaya.

Hasil penelitan ini didukung atau diperkuat oleh Hartijasti (2001), mengatakan korelasi yang signifikan antara budaya organisasi dengan kinerja karyawan. Kebanyakan dari penelitian budaya organisasi memberi penekanan pada pentingnya nilai-nilai dan keyakinan yang berada dalam inti dari sistem sosial suatu perusahaan.

Sedangkan penelitian Megawati dan Rahayu (2002) mengatakan bahwa ada pengaruh yang signifikan antara Corporate Culture, customer orientation dan Corporate Innovatiness terhadap Corporat Performnece PT. X di Surabaya. Ini menunjukkan bahwa budaya organisasi sangat berpengaruh terhadap kinerja karyawan dalam melaksanakan aktivitas kerja.

Hasil penelitian Radiany (2004) juga menujukkan bahwa ada pengaruh yang signifikan antara budaya organisasi terhadap koalitas pelayanan pada PTS di Kalimantan Selatan. Penelitian ini menunjukkan bahwa kualitas pelayanan dipengaruhi oleh budaya organisasi yang berupa perhatian pada rincian, orientasi pada hasil, orientasi pada orang dan orientasi pada tim.

Perusahaan yang mengkombinasikan nilai dan keyakinan, kebijakan dan praktek manajemen, serta hubungan antara keduanya akan menunjukkan keberhasilan yang terlihat dari budaya organisasi yang memiliki sifat keterlibatan, konsistensi, adaptabilitas, dan penghayatan misi. Perusahaan yang efektif yaitu perusahaan yang membudayakan nilai-nilai yang diperlukan untuk kepentingan operasi perusahaan. Oleh karena itu budaya organisasi yang benar-benar dikelola sebagai alat manajemen akan berpengaruh dan menjadi pendorong bagi karyawan untuk berperilaku positif, dedikatif, dan produktif. Nilai-nilai budaya itu tidak tampak, tetapi merupakan kekuatan untuk mendorong perilaku untuk menghasilkan efektifitas kinerja.

\section{Pengaruh Stres Kerja Terhadap Kinerja Karyawan}

Berdasarkan hasil penelitian, dapat diketahui ada pengaruh yang signifkan antara stres kerja terhadap kinerja karyawan CV. Bintang Karya Putra di Surabaya, artinya bahwa stres kerja dapat dijadikan sebagai dasar untuk memprediksi kinerja karyawan CV. Bintang Karya Putra di Surabaya. Ini menunjukkan bahwa kinerja karyawan CV. Bintang Karya Putra di Surabaya sangat dipengaruhi oleh stres kerja seorang karyawan atau sekelompok karyawan .

Hasil penelitian ini didukung oleh penelitian Sukemi (2007), mengatakan secara simultan variabel stres kerja dan semangat kerja mempunyai pengaruh yang signifikan terhadap kinerja karyawan. Stres kerja yang terjadi di CV. Bintang Karya Putra di Surabaya bersumber dari tuntutan tugas atau beban kerja yang berlebihan, tekanan atau 
keterdesakan waktu. Sedangkan hasil penelitian Ferijani dan Rahutami (2001) mengatakan bahwa stres berpengaruh signifikan terhadap kinerja karyawan. Untuk memahami sumber stress kerja, kita harus melihat stress kerja ini sebagai interaksi dari beberapa faktor, yaitu stress di pekerjaan itu sendiri sebagai faktor eksternal, dan faktor internal seperti karakter dan persepsi dari karyawan itu sendiri.

Stres kerja dapat memiliki pengaruh positif maupun negatif dan keduanya dapat terjadi dalam jangka pendek maupun jangka panjang. Akibat dari stres banyak yang bervariabel. Stres yang bersifat positif, seperti motivasi pribadi, rangsangan untuk bekerja lebih keras, dan meningkatnya inspirasi hidup yang lebih baik. Dalam hal ini, untuk menyikapi stres dan dampak stres lebih ditujukan pada pemilihan pekerja yang sesuai dengan pekerjaanpekerjaan tersebut. Cara lain yang dapat dipergunakan untuk mengurangi stres dan dampaknya adalah dengan mengubah persepsi pekerja mengenai pekerjaan dan kemampuannya. Pengaruh stres kerja ada yang menguntungkan maupun merugikan bagi perusahaan. Namun pada taraf tertentu pengaruh yang menguntungkan perusahaan diharapkan akan memacu karyawan untuk dapat menyelesaikan pekerjaan dengan sebaikbaiknya dan pada gilirannya akan mampu meningkatkan kinerja.

\section{Pengaruh komitmen terhadap Kinerja Karyawan}

Berdasarkan hasil penelitian, dapat diketahui ada pengaruh yang signifikan antara komitmen terhadap kinerja karyawan CV. Bintang Karya Putra di Surabaya, artinya bahwa komitmen dapat dijadikan sebagai dasar untuk memprediksi terhadap kinerja karyawan CV. Bintang Karya Putra di Surabaya.

Penelitian ini diperkuat oleh temuan Koesmono (2004), mengatakan bahwa komitmen organisasi berpengaruh positif terhadap kinerja karyawan pada perusahaan Perayuan di Jawa Timur. Sedangkan Suryanto (2002) hasil temuanya mengatakan kinerja organisasi sangat ditentukan oleh besarnya komitmen dari para anggotanya. Keterlibatan psikologis ini akan tercermin pada tingkat aktivitas seseorang tersebut dalam suatu organisasi dan untuk kepentingan organisasi.

Studi Chen (2004) mendukung hasil penelitian ini karena hasil penelitiannya menunjukkan bahwa budaya organisasi dan gaya kepemimpinan berpengaruh signifikan positif terhadap komitmen organisasi, kepuasan kerja dan kinerja karyawan. Pendapat lainnya dikemukakan oleh Furtwengler (2002) yang mengemukakan bahwa untuk meningkatkan kinerja pegawai, maka organisasi perlu melakukan perbaikan kinerja. Adapun perbaikan kinerja yang perlu diperhatikan oleh organisasi adalah faktor kecepatan, kualitas, layanan, dan nilai. Keberhasilan suatu organisasi sangat dipengaruhi oleh kinerja individu karyawannya. Setiap organisasi maupun perusahaan akan selalu berusaha untuk meningkatkan kinerja karyawan, dengan harapan apa yang menjadi tujuan perusahaan akan tercapai. Dari penjelasan tersebut di atas ada keterkaitan antara komitmen dengan kinerja karyawan. 
Hasil penelitian lain yang juga mendukung penelitian ini yaitu Sutarso dan Suryani, (2002) hasil penelitiannya menunjukkan bahwa dengan membangun komitmen organisasi melalui pendekatan relationship marketing mampu meningkatkan daya saing organisasi. Ini menujukkan sebagai organisasi akan senantiasa mencari informasi tentang apa yang dibutuhkan dan diinginkan anggotanya, aktif melakukan inteligensi tentang apa yang dilakukan oleh organisasi pesaing dan unsur-unsur yang terkait dengan lingkungan organisasinya agar dapat memberikan yang terbaik bagi anggotanya.

Sedangkan penelitian Sutrisno (2005), mengatakan bahwa ada pengaruh yang signifikan antara kualitas kekaryaan dan komitmen terhadap kinerja organisasi Pada Dinas Pariwisata Propinsi Jawa Timur. Hasil penelitian yang serupa juga dinyatakan oleh Prasetyo (2002) yaitu bahwa terdapat pengaruh yang signifikan antara kepuasan kerja dan komitmen organisasi terhadap semangat kerja karyawan. Ini menunjukkan bahwa komitmen merupakan sesuatu hal yang sangat dibutuhkan oleh perusahaan untuk meningkatkan kinerja karyawan.

Oleh karena itu perubahan organisasi sangat diperlukan. Ini menunjukkan bahwa perubahan organisasi akan terwujud apabila mulai dari pimpinan sampai bawahan mempunyai komitmen yang tinggi untuk mendukung perubahan tersebut, pada gilirannya akan mampu meningkat kinerja karyawan. Perubahan yang dimaksud meliputi: perubahan dalam perilaku, perubahan dalam sistem nilai dan penilaian, perubahan dalam metode dan cara-cara kerja, perubahan dalam peralatan yang digunakan, perubahan dalam cara berfikir dan perubahan dalam hal bersikap.

\section{IMPLIKASI}

Penelitian ini ditujukan untuk memberikan justifikasi ilmiah apakah budaya organisasi, stres kerja dan komitmen berpengaruh terhadap kinerja karyawan CV. Bintang Karya Putradi Surabaya. Temuan ini mengungkapkan bahwa budaya organisasi merupakan faktor kunci yang sangat berpengaruh terhadap kinerja karyawan CV. Bintang Karya Putra di Surabaya. Faktor yang membentuk budaya organisasi adalah komitmen dan stres kerja.

\section{SIMPULAN}

1. Berdasarkan hasil penelitian dapat diketahui bahwa ada pengaruh yang signifikan antara budaya organisasi terhadap kinerja karyawan CV. Bintang Karya Putra di Surabaya.

2. Berdasarkan hasil penelitian dapat diketahui bahwa ada pengaruh yang signifikan antara stres kerja terhadap kinerja karyawan CV. Bintang Karya Putra di Surabaya. 
3. Berdasarkan hasil penelitian dapat diketahui bahwa ada pengaruh yang signifikan antara komitmen terhadap kinerja karyawan CV. Bintang Karya Putra di Surabaya.

4. Variabel yang paling dominan berpengaruh terhadap kinerja karyawan CV. Bintang Karya Putra di Surabaya adalah variabel budaya organisasi.

5. Kontribusi yang diberikan oleh budaya organisasi, stress kerja dan komitmen terhadap kinerja organisasi CV. Bintang Karya Putra di Surabaya sebesar 83,50 \%. Sedangkan sisanya $16,50 \%$ adalah merupakan variabel-variabel yang tidak terprediksi dalam penelitian ini.

\section{DAFTAR PUSTAKA}

Chen, Li Yueh. 2004. "Examining The Effect Of Organization Culture And Leadership Behaviors On Organizational Commitment, Job Satisfaction, Adan Job Performance At Small And Middle-Sized Firma Of Taiwan," Journal of American Academy of Business, Sep 2004, 5, 1/2, hal 432-438.

Ferijani, A dan Ika Rahutami. 2001. "Stres Kerja karyawan BPR (Studi Kasus Perbarindo Komda Semarang)". Jurnal Dian Ekonomi. Vol.VII. No.1.hal 9-18.

Furtwengler, Dale. 2002. Penilaian Kinerja, Menguasai Keahlian Yang Anda Perlukan Dalam 10 Menit. Diterjemahkan oleh Fandy Tjiptono.. Yogyakarta: Andi Press

Hartijasti, Yenki. 2001. Hubungan antara Budaya Organisasi dengan Kinerja Perusahaan, Jurnal Ilmiah Psikologi Terapan, Phronesis, Vol. 3 No. 5 Juni 2001.hal 1-19.

Koesmono, Teman. 2004. Pengaruh Kepribadian terhadap Komitmen Organisasi dan Perilaku serta Kinerja Karyawan pada Perusahaan Perkayuan di Jawa Timur Jurnal Widya Manajemen \& Akuntansi, Volume 4 Nomor 3, Desember 2004.hal 235-247.

Mangkunegara, A. A. Prabu. 2005. Evaluasi Kinerja Sumber Daya Manusia. Bandung: Refika

Megawati, Veny dan Rahayu, Siti. 2002. pengaruh Corporate Culture, Customer Orientations dan Corporate Innovativeness Terhadap corporate Performance PT. X. Surabaya (Proceeding Temu Ilmiah I APIO tgl. 2-3 Agusus 2003, hal 231242).

Miner, John B. 1990. Organizational Behavior: Performance and Productivity, New York: Random House, Business Division. 
Moeljono Djokosantoso. 2003. Budaya Korporat dan Keunggulan Korporasi, Jakarta: Elex Media Komputindo

..................................... .2005. Cultured, Budaya Organisasi Dalam Tantangan. Jakarta : PT Elex Media Komputindo.

Prasetyo, gendut Sukarno. 2002. Analisis Pengaruh Kepuasan Kerja dan Komitmen Organisasi Terhadap Semangat Kerja Karyawan (Kurnal Ventura, jurnal Ekonomi dan Akuntasi, Vol.7 No. 3, Desember 2004, hal 24-33)

Radiany, Rahmady. 2004. Pengaruh Budaya Organisasi Terhadap kualitas pelayanan Pada PTS di Kalimantan Selatan (Jurnal Kindai, Jurnal Ilmiah Manajemen dan Akuntasi Vol.1 No.1 1 Januari 2004, hal 35-45).

Rivai Veithzal. 2005. Manajemen Sumber daya Manusia Untuk Perusahaan dari Teori ke Praktik, Jakarta : PT. Rajagrafindo Persada.

Robbins SP, dan Judge. 2007. Perilaku Organisasi. Jakarta : Salemba Empat.

Robbins, Stephen P. 2006. Perilaku Organisasi, Edisi kesepuluh, Jakarta: PT Indeks.

Sasono, Eko. 2004. Mengelola Stres Kerja. Jurnal Fokus Ekonomi. Vol III. No.2. hal 48-56.

Sopiah. 2008. Perilaku Organisasi, Yogyakarta : Andi Offset.

Sugiyono. 2003. Metode Penelitian Bisnis, CV. Alfabeta, Bandung, 2003.

Sukemi. 2007. Pengaruh Stres Kerja dan Semangat Kerja terhadap Kinerja Karyawan, Jurnal Ilmiah Psikologi Terapan, Phronesis, Vol. 9 No. 4 Juni 2007.hal 12-20.

Sulistiyani, Ambar Teguh. dan Rosidah, 2003, Manajemen Sumber Daya Manusia: Konsep, Teori dan Pengembangan dalam Konteks Organisasi Publik. Yogyakarta: Graha Ilmu.

Suryanto, 2002, Komitmen Organisasi: Perspektif psikologi Sosial (Proceeding Temu Ilmiah I APIO tgl. 2-3 Agusus 2003, hal 148-155).

Susanto. 1997. Budaya Perusahaan, Manajemen dan Persaingan bisnis, PT. Elex Media Komputindo, Jakarta. 
Sutarso Yadi dan Suryani Tatik. 2002. Membangun Komitmen Organisasi Melalui Pendekatan Relationship Marketing Bagi Peningkatan Daya Saing Organisasi, Proceeding Temu Ilmiah I APIO, Asosiasi Psikologi Industri \& Organisasi tgl 2-3 Agustus 2002, hal 156-166.

Sutrisno, Edy. 2005. "Pengaruh kualitas Kekaryaan dan Komitmen Terhadap Kinerja Organisasi Pada Dinas Pariwisata Propinsi Jawa Timur”. Jurnal Ekonomi dan Bisnis ISSN 1410-7465. 9(Januari), hal 17-28. 